\title{
MOTHER'S KNOWLEDGE ABOUT NUTRITION WITH BEHAVIOR OF FEEDING IN PUSKESMAS BOTTANIA BATAM CITY
}

\author{
Mohd Faisyal Reza ${ }^{1}$, Efilona Setri ${ }^{2}$ \\ mohdfaisyalreza@univbatam.ac.id ${ }^{1}$, efilonasetri@univbatam.ac.id ${ }^{2}$ \\ 1Professional Doctor Study Program, Faculty of Medicine, Batam University ${ }^{1}$ \\ 2 Medical Education Study Program, Faculty of Medicine, University of Batam ${ }^{2}$ \\ Jl. Abulyatama No 5 - Kota Batam
}

\begin{abstract}
Background :Nutritional problems are a complex problem not only due to powerlessness or economic inadequacy, but also regarding knowledge, attitudes and behavior. The practice of giving food to infants and children, especially at the age of 0-23 months, must be carried out correctly and appropriately. Feeding errors in this period can lead to malnutrition and stunting. The purpose of this study was to determine the knowledge of mothers about nutrition with feeding behavior in toddlers.
\end{abstract}

Method :The research method used was an analytic survey with a cross sectional approach. Conducted at Botania puskesmas, the study was conducted for 6 months, the population in this study were toddlers' mothers who came to the Botania puskesmas. The sample in this study was 40 people. The sampling technique was carried out by accidental sampling technique with research instruments using a questionnaire. Data analysis using Chi square.

Result : The results of the research on maternal knowledge about good toddler nutrition were equal to the frequency of maternal knowledge about adequate nutrition, namely (20) respondents $(50 \%)$, the majority of toddlers' feeding behavior was good (22) toddlers $(55 \%)$. Chi-square statistical test obtained $\mathrm{p}$-value $=0.00<0.05$,

Conclusion : there is a significant relationship between maternal knowledge about nutrition and feeding behavior of children under five at Botania Health Center. Suggestions that the authors provide to provide health education, especially nutrition for toddlers

Keywords: Knowledge, Mother, Toddler Nutrition, Toddler Feeding

\section{PRELIMINARY}

The high number of cases of malnutrition in Indonesia shows the low level of public awareness about nutrition. Lack of knowledge and misperceptions about food needs and food value are common in every country in the world. Poor nutrition knowledge results in a lack of knowledge or information about nutrition to apply this information in daily life. -day. Nutritional problems are a complex problem not only due to powerlessness or economic inadequacy, but also regarding knowledge of attitudes and behaviors.

Balanced nutrition for children aged 0-2 years starting from conception until the first year of birth, this period is a period of crisis, this period the brain cells have reached more than $80 \%$. Malnutrition at this time of life needs serious attention. A balanced diet, the baby will grow and develop optimally, including his intelligence. Lack of attention from parents, especially mothers during this crisis period, failure to develop optimally will be carried 
over to adulthood permanently. If the pattern of breastfeeding or complementary feeding is not sufficient for the nutritional needs of the body, infants and toddlers will experience growth problems (WHO, 2010) Two years of age, the growth and development of children need adequate nutrition, which is influenced by internal factors in the form of genetics and external factors in the form of daily food intake. 3 Based on 2011 WHO data, the prevalence of malnourished children in Indonesia reaches $13 \%$ and the mortality rate due to malnutrition reaches $54 \% .4$ According to Riskesdas 2010 data, the prevalence of malnutrition in children in Central Java province was $17.9 \%$ and for malnutrition it reached $4.9 \%$. One of the causes of malnutrition in children is the improper feeding practice for children. 5 Based on 2010 WHO data, 1.5 million children died due to improper feeding and $90 \%$ of them occurred in developing countries

Mother's behavior in fulfilling nutrition includes food preferences, eating behavior, and energy intake which are closely related to the nutritional status of the child. Mother's behavior, including knowledge, attitudes and actions in fulfilling nutrition, is one of the factors causing nutritional problems in toddlers. From the results of the survey on mothers in the nutritional fulfillment of toddlers, it is illustrated that, $63 \%$ of mothers have less knowledge, $50 \%$ of mothers often follow the will of toddlers in choosing foods including snacks, while $75 \%$ of mothers provide food without paying attention to the nutritional content.

The provision of food to children can be influenced by the knowledge and attitudes of the mother and the support of the family and the environment. Knowledge and attitudes of mothers will affect the intake of food in the family, especially children.7,8 Research conducted by Rinda shows that only about $62.5 \%$ of mothers can practice balanced feeding behavior to children, $75 \%$ of which have a positive attitude in providing balanced nutritious food and $54.2 \%$ of mothers who only understood nutritionally balanced diet but could not practice it well.

Based on research conducted by Lucky Resha Hardiani (2015) regarding the level of knowledge of mothers about nutrition with nutritional status of toddlers at the Sambau Health Center, data collection was carried out by filling out a questionnaire with a total of 42 respondents. In August 2015, the mother's knowledge of high nutrition was 25 respondents $(59.5 \%)$ and the mother's knowledge of low nutrition was 17 respondents $(40.5 \%)$.

Research conducted by Evan shows that nutrition education for parents or families with children can change the behavior of the family, especially in feeding. Research conducted by Ertem shows that giving the right food intake will be greatly influenced by the family so that it can affect the food intake and nutritional status of the child. Proper feeding includes main feeding and snacks to children.

Based on data from the Batam City Health Office in 2015, it is known that there are as many as 151,203 toddlers in Batam City, the number of toddlers who are weighed as many as 91,240 under five, and it is known that 466 toddlers $(0.49 \%)$ have poor nutritional status, as many as 2.952 under five $(3,24 \%)$ had a poor nutritional status, and 86.136 children under five $(94.41 \%)$ had a good nutritional status, and as many as 1.706 infants $(1.87 \%)$ had more nutritional status.

In addition, according to data from the Batam City Office in 2016, the first prevalence of the number of children under five with malnutrition and lack of nutrition in Botania Puskesmas was 583 (17.2\%). 
Based on the data above, it shows that nutritional problems are still found in toddlers and the authors are interested in conducting research and take the title Mother's Knowledge Relationship About Nutrition with feeding behavior in toddlers.

\section{RESEARCH PURPOSES}

This is to determine the relationship between maternal knowledge about nutrition and feeding behavior for children under five at Botania Public Health Center

\section{RESEARCH METHODS}

The research method used was an analytic survey with a cross sectional approach. Conducted at the Botania puskesmas, the study was conducted for 6 months, the population in this study were toddlers' mothers who came to the Botania puskesmas. The sample in this study was 40 people. The sampling technique was carried out by accidental sampling technique with research instruments using a questionnaire. Data analysis using Chi square

\section{RESEARCH RESULT}

From the results of research conducted on Mother's Knowledge Relationship about Toddler Nutrition with Feeding Behavior for Toddlers at the Botania Health Center, Batam City, with the following results:

It is known that the frequency distribution of maternal knowledge about good toddler nutrition is equal to the frequency of maternal knowledge about adequate nutrition for children under five, namely (20) respondents (50\%).

It is known that the distribution of the frequency of feeding behavior to the majority of children under five is good, as many as 22 respondents $(55 \%)$ and less as many as 10 respondents (45\%).
Based on the bivariate analysis, it can be seen that mothers with good knowledge are as many as 20 respondents (50\%) with feeding behavior to toddlers in good categories as much as $17(85 \%)$, while mothers with good knowledge are less than $3(15) . \%)$. Of the $20(50 \%)$ mothers with sufficient knowledge of good feeding behavior to toddlers as many as $5(25 \%)$. Meanwhile, the mother's knowledge is sufficient with the feeding behavior to less than 15 children (75\%).

From the results of the Chi-Square calculation, the $p$-value is 0.00 because the $\mathrm{p}$-value is $<0.05$, so it can be concluded that Ho is rejected. This shows that there is a relationship between the knowledge of mothers about toddler nutrition and the feeding behavior of toddlers at the Botania Community Health Center

\section{DISCUSSION \\ Mother's knowledge about toddler nutrition}

Based on the results of the study, it is known that the number of respondents was 40 in mothers at the Botania Community Health Center, Batam City in 2017, showing that the knowledge of mothers about good nutrition for toddlers was 20 people $(50 \%)$ and knowledge of mothers about adequate nutrition for toddlers was 20 people $(50 \%)$. Based on these data, it is known that the frequency level of mother's knowledge is good and sufficient, which is the same. This is influenced by the respondents 'answers that vary based on the respondents' insights and experiences.

Knowledge is the result of knowing, and this happens after people have sensed a certain object. Knowledge occurs after people sense through the five senses, sight, hearing, smell, taste and touch. Most of human knowledge is obtained through the eyes and ears. Knowledge or cognitive is a 
very important domain for the formation of one's actions (Notoatmodjo, 2003). According to Arikunto (2006), the behavioral assessment stage is as follows: can use questions about knowledge from the mother. Supplementary or complementary foods with breastfeeding are foods or drinks that contain nutrients, given to babies or children aged 6-24 months to meet nutritional needs other than breast milk. (MOH, 2006)

Knowledge is influenced by intrinsic and extrinsic factors. The extrinsic factors include education, employment, the state of the material to be studied. Meanwhile, the intrinsic factors include age, ability and will or will. By increasing and optimizing the intrinsic factors that are in oneself and extrinsic factors, it is expected that the mother's knowledge will increase (Notoatmojo, 2003).

From the results of the study, the level of education of mothers that was mostly found was high school graduates (33.8\%). Education can affect a person's learning process, the higher one's education, the easier it will be to receive existing information. The more information that comes in, the more knowledge will be obtained, including information about health. The higher a person's education, the higher one's knowledge will be. However, someone with low education is not necessarily low-knowledge either

This research is in line with research conducted by Lucky Resha Hardiani (2015) regarding the level of knowledge of mothers about nutrition with nutritional status of toddlers at the Sambau Health Center. Data collection was carried out by filling out a questionnaire with a total of 42 respondents. In August 2015, the mother's knowledge of high nutrition was 25 respondents $(59.5 \%)$ and the mother's knowledge of low nutrition was 17 respondents $(40.5 \%)$.
This is also in line with research conducted by Kristianto (2013) entitled Factors Influencing Mother Behavior in Companion Feeding for Babies aged 6-36 months of education of the majority of respondents are high school. The level of education at the high school level can already be said to be advanced education, so that the level of knowledge of the respondents also increases in proportion to the level of education that has been taken . Education can influence a person including one's behavior in life patterns, especially in motivating to participate in development, the higher education the easier it is to get information

\section{Feeding behavior in toddlers}

Based on the results of the study it is known that the behavior of mothers giving good food to toddlers as many as 22 toddlers $(55 \%)$,

Mother's behavior in fulfilling nutrition includes food preferences, eating behavior, and energy intake which are closely related to the nutritional status of the child. Mother's behavior, including knowledge, attitudes and actions in fulfilling nutrition, is one of the factors causing nutritional problems for Toddler

High education can affect the behavior of mothers in feeding their children. Mothers who have higher education are expected to have a better acceptance of the knowledge received so that they are expected to be practiced in the family. However, low education does not guarantee that a mother does not have enough knowledge about food in the family. The existence of high curiosity can influence mothers in getting information about the right food for their children. While research conducted by Henny shows a significant relationship between maternal knowledge and feeding to toddlers. Other research conducted by Kodyat shows that 
higher education can make it easier in digesting information so that it influences knowledge

\section{The Relationship between Mother's Knowledge of Nutrition and Feeding Behavior in Toddlers}

Based on the bivariate analysis, it can be seen that mothers with good knowledge are 20 respondents $(50 \%)$ with 17 (85\%) good category feeding behavior, based on Chi-Square analysis, the p-value is 0.00 because of the results. p-Value $<0.05$, so it can be concluded that Ho is rejected. This shows that there is a relationship between the knowledge of mothers about toddler nutrition and the feeding behavior of toddlers at Puskesmas Botania

The level of a person's nutritional knowledge affects the attitude and behavior in choosing food which determines whether or not a person is easy to understand the benefits of the nutritional content of the food consumed. Good nutritional knowledge is expected to affect the consumption of good food, so that it can lead to a good nutritional status as well. Nutritional knowledge also has a very important role in the formation of a person's eating habits so that the health education that is given can influence the behavior of mothers about balanced nutrition for toddlers to be better.

The results of this study were supported by research conducted by Ikhwansyah, where education and knowledge would have a significant relationship with mother's behavior in feeding. Information about nutrition in toddlers can increase the mother's knowledge, the more often the mother gets health information the better the mother's knowledge of balanced nutrition, the better it is in calculating the type and amount of food she gets for consumption. Extension of balanced nutrition is important to increase knowledge of balanced nutrition for mothers who have toddler. Efforts to increase knowledge of maternal healthnutrition through counseling are the right steps to be taken by parents and supported by parties who care about mothers and children. This means that the better the knowledge of maternal health-nutrition, the child's growth will also improve.

This is in line with Suwarto's research (2008) that there is a relationship between knowledge about nutrition and the provision of nutritious food consumption to children under five according to their nutritional status. The results of statistical analysis showed the values so that knowledge about nutrition had a positive and significant relationship with the provision of nutritious food consumption to children under five according to their nutritional status.

\section{CONCLUSION}

1. Maternal knowledge about toddler nutrition at Puskesmas Botania, Batam City, with 20 respondents (50\%) having good knowledge is the same as respondents who have sufficient knowledge.

2. Mother's behavior in feeding to toddlers at Botania Health Center, Batam City is mostly good, as many as 22 people $(55 \%)$.

3. There is a significant relationship between the knowledge of mothers about toddler nutrition and the feeding behavior of toddlers at the Botania Community Health Center, Batam City, with a p-value of 0.00

\section{SUGGESTION}

Based on the research that has been done, the researcher will provide suggestions that can be used as input later.

1. For mothers who have toddlers 
It is hoped that this can increase knowledge and insight about the importance of fulfilling nutritional status and care more about toddler nutrition so that they can assess the nutritional development of their children.

2. For Health Workers and Puskesmas It is hoped that health workers and puskesmas will be more active in providing health education about the nutritional status of toddlers so that all mothers have good knowledge about the nutritional status of children under five. And it is hoped that the health center can form a program for mothers under five classes in which there is health education related to important nutrition for toddlers.

3. For Batam University Institutions From the results of this research it is hoped that it can provide benefits to add information and can be used as library material.

4. For Further Researchers

From the research results, it is hoped that it can be used as reference material for future researchers who will conduct the same research. Researchers also really hope that further researchers can research with a larger number of samples, different places and a more appropriate way in coordination with health workers or cadres so that they can condition respondents to make it easier for researchers to conduct research.

\section{BILBOGRAPHY}

Anjani, A. D. (2017). PENGARUH PEMBERIAN PROMOSI KESEHATAN TERHADAP PENINGKATAN PENGETAHUAN IBU NIFAS TENTANG BAHAYA PEMBERIAN MP-ASI DINI. Jurnal Kebidanan Malahayati, 3(3).
Anjani, A. D. (2018). FAKTOR FAKTOR YANG BERHUBUNGAN DENGAN IBU YANG MEMBAWA BALITA TIMBANG KE POSYANDU. Jurnal Kebidanan Malahayati,4(2).

Aulia, Devy lestari Nurul (2018). Pengaruh Pemberian Promosi Kesehatan Terhadap Pengetahuan Ibu Tentang Perkembangan Motorik Halus Pada Anak Prasekolah Usia 3-5. Jurnal Kebidanan Malahayati 4(1)

Dainty Maternity, S. S. T., Keb, M., \& Anjani, A. D. (2018). ASUHAN KEBIDANAN NEONATUS, BAYI, BALITA, DAN ANAK PRASEKOLAH. Penerbit Andi

Dewi, dkk. 2010. Hubungan Pola Pemberian Makanan Pendamping Asi (MP-ASI) Dengan Status Gizi Pada Balita Usia 6-12 Bulan Di Desa Kaliori Kecamatan Kalibagor Kabupaten Banyuma.YLPP Purwokerto : Jurnal

Ehok, dkk. 2015. Hubungan Tingkat Pengetahuan Ibu Tentang Makanan Pendamping Air Susu Ibu Terhadap Status Gizi Bayi Usia 6-12 Bulan Di Wilayah Kerja Puskesmas Pakis. Universitas Katolik Widya Mandala Surabaya : Skripsi.

Ezzat, Sally. 2007. Factors Affecting Complementary Feeding Pattern in Alexandria.Bulletin of High Institute of Public Health, Vo. 37 No. 48.

Hestuningtyas, T.R.2013.Pengaruh Konseling Gizi terhadap pengetahuan, sikap,praktik ibu dalam pemberian makan anak dan asupan zat gizi anak stunting usia 1 -2 tahun di kecamatan Semarang Timur. Semarang: Fakultas Kedokteran Universitas Diponegoro. Artikel Penelitian.

Jumyati, 2016.Nutrition Education Improves Mother's Knowledge and Attitude in the provision of Complementary Foods. International Conference on Health and Well Being 2016. Articles 
Kurniawati (2011) Hubungan Tingkat Pengetahuan Ibu Tentang Gizi dengan Status GIZI Balita si Kelurahan Baledono, Kecamatan Purworejo, Kabupaten Purworejo, Karya Tulis Ilmiah tidak diterbitkan

Kolifah, dkk. 2014. Pengaruh PerilakuIbu Dalam Memberikan Makanan Pendamping ASI Terhadap Status Gizi Bayi Usia 7-12 Bulan. Jombang : Jurnal

Manikyamba et al. 2015.Impact of Nutritional Education on the Knowledge of Mothers regarding Infant and Young Child Feeding Practices. Scholars Journal of Applied Medical Sciences (SJAMS) 2015: 3 (34):1074-1078. ISSN 2347-954X.

Maternity, Dainty; Ratna, DP; Devy, LNA. (2017). Asuhan Kebidanan KomunitasDisesuaikan dengan Rencana Pembelajaran Kebidanan. Penerbit Andi, Yogyakarta

Marmi. 2013. Gizi dalam Kesehatan Reproduksi. Yogyakarta : Pustaka Pelajar.

Notoatmodjo, Sukidjo. 2010. Metode Penelitian Kesehatan. Jakarta: Rineka Cipta

Nurul Aulia, D., \& Anjani, A. (2019). Hubungan Pengetahuan dan Sikap Ibu Balita dengan Perilaku Keluarga Sadar Gizi (KADARZI). Journal for Quality in Women's Health, 2(1), 36-42. Retrieved from

https://www.jqwh.org/index.php/JQWH/a rticle/view/25

Prihati, dkk. 2009. Hubungan Pengentahuan Ibu Tentang Makanan Pendamping ASI (MP-ASI) Dengan Status Gizi Balita Usia 6-23 Bulan Di
Desa Parangjoro Kabupaten Sukoharjo. Poltekes Kemenkes Surakarta : Jurnal

Rahmawati (2016) Hubungan antara Pengetahuan Ibu Tentang Gizi Seimbang dan Asupan Zat Gizi Makro Pada Anaka Usia 2-5 tahun di Posyandu Gonilan Kartasura, Karya Tulis Tidak diterbitkan. Universitas Muhammadiyah

Respati, Fitri . 2012 .Gizi dalam siklus daur kehidupan 1 Manusia. Jakarta: PT Primamedia Pustaka.

Resha, Lukcy (2015) Hubungan pengetahuan ibu tentang gizi dengan status gizi balita. Karya Tulis Ilmiah tidak diterbitkan. Universitas Batam. Kepulauan Riau.

Utami, Dian (2015) Hubungan pengetahuan ibu terhadap Status Gizi Balita. Skripsi tidak diterbitkan .Universitas Batam. Kepulaun Riau.

Susanti, Rika dkk . 2014. Hubungan Pengetahuan Ibu Tentang Gizi Denga Status Gizi Anak Usia 1-3 Tahun. Skripsi tidak diterbitkan. Universitas Riau.

Selfya (2014) Hubungan antara tingkat pengetahuan ibu tentang kontrasepsi suntik DPMA dengan kepatuhan jadwal penyuntikan ulang di Puskesmas Sukaramai. Karya Tulis Ilmiah tidak diterbitkan . Universitas Sumatra Utara.

Diskesriau.net/downlot,php?...Profil\%20 Kesehatan\%20Provinsi\%20Riau\%20t ahun\%2015.Diakses Tanggal 18 maret 2017.

http://www.depkes.go.id/resources/downlo ad.pusdatin.Profil-kesehatan indonesia/profil-kesehatan-indonesia2015. Diakses tanggal 11 maret 2017 